Acta vet. scand. $1981,22,428-434$.

From the Department of Pathology, Royal Veterinary and Agricultural

University, Copenhagen, Denmark.

\title{
IMMUNOGLOBULIN LEVELS \\ IN NON-ABORTED AND ABORTED FETUSES FROM DANISH HERDS OF CATTLE
}

\author{
By \\ H. Bielefeldt Ohmann
}

\begin{abstract}
OHMANN, H. BIELEFELDT: Immunoglobulin levels in non-aborted and aborted fetuses from Danish herds of cattle. Acta vet. scand. $1981,22,428-434$. - The applicability of serological tests in the diagnosis of intrauterine infections in Danish cattle was investigated. Fetuses from slaughter animals, experimentally infected and spontaneously aborted fetuses, premature and stillborn calves, were subjected to necropsy and histological studies, and to microbiological and serological examinations. The latter comprised rocket immunoelectrophoresis and radial immunodiffusion. In sera of the fetuses from slaughter animals, immunoglobulins were either not detectable or only present in very small quantities, whereas sera of fetuses and calves with pathological changes and/or verified infection contained considerable amounts of IgM and IgG. IgA was also detected in the latter group. The results corroborate the diagnostic importance of immunoglobulin determination in aborted fetuses and stillborn calves.
\end{abstract}

bovine fetuses; intrauterine infection; immunoglobulins; cat 1 e.

Apparently, no overall picture of abortion as a contribution to reproductive failure in Danish cattle stock is available. This applies to the incidence as well as to the significance of various infectious and non-infectious causes.

From all over the world serological investigations have come widely into use as a contribution to establishing a diagnosis of fetal infection as a cause of abortion. It is assumed that no transplacental transfer of immunoglobulins to the bovine fetus will occur during a normal pregnancy (Brambell 1970). Further, it has been shown that normal precolostral calf serum contains only small amounts of immunoglobulins, if any (Sawyer et al. 1973, Ellis et al. 1978). However, following the first appearance 
of immune reactivity around day $\mathbf{9 0}$ of gestation the fetus gradually gains competence to infectious and non-infectious antigens (Schultz 1973). Factors resulting in antigenic stimulation of the bovine fetus may be of significance for bovine abortion (Miller \& Quinn 1975, Kirkbride et al. 1977, Ellis et al.). The objects of the present study were to assess the applicability of serological tests for purposes of diagnosis of intrauterine infections in Danish cattle and to establish the comparative value of results available from abroad.

\section{MATERIALS AND METHODS}

Fifty-three bovine fetuses were collected at an abattoir. Ages of fetuses were estimated from tabular data based on the relationship of age to crown-rump length and weight measurements (Hubbert et al. 1972). Blood was collected from the brachial vessels, the serum separated and stored at $-20^{\circ} \mathrm{C}$ until investigated. From six fetuses, less than ten weeks, amniotic, pleural and abdominal fluids were collected and used alternatively to serum. Eight aborted fetuses, two prematurely delivered calves and three calves stillborn at normal term were submitted for autopsy. Blood was collected as above or from the heart. Alternatively, from two fetuses serosanguinous pleural fluid was used. Five fetuses, five to six months of gestational age, formed part in an experiment, in which four fetuses were infected experimentally in utero with bovine viral diarrhea virus (BVDV) and one received a sham-inoculum (Ohmann et al. $1981 \mathrm{~b}$ ). Tissue samples were collected for microbiological and morphological studies. The histological examinations were carried out on formalin-fixed specimens stained with haematoxylin-eosin. Tissue samples from all fetuses were examined for cytopatogenic viral agents by inoculating supernatants of ground tissue onto bovine kidney cell cultures. Following one subcultivation all samples were tested for the presence of noncytopathogenic BVDV by indirect immunofluorescence (Ohmann et al. 1981 a). From ten animals, including the five experimental fetuses, tissues were additionally examined for BVDV-antigen by immunocytochemical methods (Ohmann et al. 1981 a). Routine bacteriological examination was carried out on tissue samples from 35 fetuses.

Rocket immunoelectrophoresis for the detection of IgG and IgM was essentially performed as outlined by Dalsgaard et al. (1979), using a phosphate buffer, pH 7.0 (Olitzki 1959), rabbit- 
anti-bovine IgG (DAKO Immunoglobulins, DK) and rabbit-antibovine IgM (Miles Lab. Ltd, Slough, UK). Electrophoresis was always done in parallel to a pooled sample of serum from clinically healthy, BVDV-free calves (lot NK 800807, State Veterinary Institute of Virus Research, DK). The radial immunodiffusion (RID) tests were performed with commercially prepared testkits specific for bovine IgA, IgG and IgM (Miles Lab. Ltd, Slough, UK). The diffusion-zone was read after $48 \mathrm{~h}$. Serum samples were also tested for the presence of BVDV-specific antibodies (SA), (Jensen 1981, Ohmann 1981).

\section{RESULTS AND DISCUSSION}

As will appear from Table 1, IgG was detected in four (7.7 \%) and IgM in six $(11.5 \%)$ of the fetuses from slaughter animals. As the RID was only carried out on selected samples in this group, the results are not generally representative. Except for one, all fetuses with detectable serum-immunoglobulins were older than 150 days gestational age. Only in two fetuses, eight and eight and a half to nine months respectively (Table 2), did the IgG concentration amount to that found in precolostral newborn calf serum (Sawyer et al. 1973). The specificity of the immunoglobulin was not determined. Considerable amounts of IgG and IgM were detected in all serum samples from aborted and congenitally BVDV-infected fetuses and calves. The concentrations were equal to or higher than that found in precolostral bovine calf serum (Sawyer et al., Ohmann 1981). With concentrations of more than $2.76 \mathrm{mg} / \mathrm{ml}$ in the serum of three stillborn calves (Table 2), the level may even exceed that of postcolostral newborn calf serum (Sawyer et al.). The immunoglobulins are assumed to origin from a fetal production. This is corroborated by the simultaneous presence of IgG and IgM in the absence of IgA, i.e., a selective occurrence of the former two types. Also, the absence of detectable specificity of the immunoglobulins in most fetal sera, in the presence of specific reactivity in the maternal serum (Ohmann, unpubl. data), support this assumption. $\operatorname{IgA}$ was only found in congenitally infected individuals. Although only infrequently found in fetuses of ungulates (Silverstein et al. 1963, Ellis et al. 1978), IgA may be produced in response to a persistent infection, i.e., as a result of endogenous induction of a secondary response (Ohmann 1981). 
T a b l e 1. Results of the virological bacteriological and serological investigations of $\mathbf{7 1}$ fetuses and calves.

\begin{tabular}{|c|c|c|c|c|c|c|c|c|c|c|}
\hline \multirow{2}{*}{$\begin{array}{l}\text { Gestational } \\
\text { age in } \\
\text { months }\end{array}$} & \multirow{2}{*}{$\begin{array}{c}\text { Number } \\
\text { of fetuses } \\
\text { investi- } \\
\text { gated }\end{array}$} & \multirow{2}{*}{$\begin{array}{l}\text { Viro- } \\
\text { logical } \\
\text { exami- } \\
\text { nation }\end{array}$} & \multirow{2}{*}{$\begin{array}{l}\text { Bacterio- } \\
\text { logical } \\
\text { exami- } \\
\text { nation }\end{array}$} & \multicolumn{2}{|c|}{$\begin{array}{l}\text { Rocket immuno- } \\
\text { electrophoresis }\end{array}$} & \multicolumn{3}{|c|}{$\begin{array}{l}\text { Radial immuno- } \\
\text { diffusion }\end{array}$} & \multirow{2}{*}{$\begin{array}{l}\text { Patho- } \\
\text { logical } \\
\text { changes }\end{array}$} & \multirow[t]{2}{*}{$\begin{array}{l}\text { BVDV-SA } \\
\text { in serum }\end{array}$} \\
\hline & & & & IgG & IgM & IgA & IgG & IgM & & \\
\hline \multicolumn{11}{|l|}{ abattoir } \\
\hline$\leq 2$ & 9 & $0 / 9^{z}$ & ND & $0 / 9$ & $0 / 9$ & ND & ND & ND & $0 / 9$ & $0 / 9$ \\
\hline $2-3$ & 8 & $0 / 8$ & $0 / 5$ & $0 / 8$ & $0 / 8$ & ND & ND & ND & $0 / 8$ & $0 / 8$ \\
\hline $3-4$ & 8 & $0 / 8$ & $0 / 2$ & $0 / 8$ & $1 / 8$ & $0 / 1$ & $0 / 1$ & $0 / 1$ & $0 / 8$ & $0 / 8$ \\
\hline $4-5$ & 14 & $0 / 14$ & $0 / 6$ & $0 / 14$ & $0 / 14$ & ND & $0 / 4$ & ND & $0 / 14$ & $0 / 14$ \\
\hline $5-6$ & $9 d$ & $0 / 9$ & $0 / 7$ & $1 / 9$ & $0 / 9$ & $0 / 5$ & $1 / 9$ & $0 / 4$ & $0 / 9$ & $0 / 9$ \\
\hline $6-7$ & 3 & $0 / 3$ & $0 / 1$ & $0 / 3$ & $2 / 3$ & $0 / 3$ & $0 / 3$ & $0 / 3$ & $0 / 3$ & $0 / 3$ \\
\hline $7-8$ & 2 & $0 / 2$ & $0 / 1$ & $2 / 2$ & $2 / 2$ & $0 / 2$ & $1 / 2$ & $0 / 2$ & $0 / 2$ & $0 / 2$ \\
\hline $8-9$ & 1 & $0 / 1$ & $0 / 1$ & $1 / 1$ & $1 / 1$ & $0 / 1$ & $1 / 1$ & $0 / 1$ & $0 / 1$ & $0 / 1$ \\
\hline \multicolumn{11}{|c|}{$\begin{array}{l}\text { aborted and } \\
\text { infected }\end{array}$} \\
\hline $5-6$ & $4 b$ & $4 / 4^{x}$ & $0 / 4$ & $4 / 4$ & $4 / 4$ & $1 / 4$ & $4 / 4$ & $4 / 4$ & $4 / 4$ & $2 / 4$ \\
\hline $6-7$ & $2^{a}$ & $2 / 2^{x}$ & $1 / 2^{c}$ & $2 / 2$ & $2 / 2$ & ND & ND & ND & $2 / 2$ & $1 / 2$ \\
\hline $71 / 2-81 / 2$ & $6^{\mathrm{a}}$ & $3 / 6^{x}$ & $0 / 6$ & $6 / 6$ & $6 / 6$ & $0 / 2$ & $0 / 2$ & $0 / 2$ & $5 / 6$ & $1 / 6$ \\
\hline $81 / 2-9$ & $2^{y}$ & $2 / 2^{x}$ & $1 / 2$ & $2 / 2$ & $2 / 2$ & $1 / 2$ & $2 / 2$ & $2 / 2$ & $2 / 2$ & $0 / 2$ \\
\hline 9 & $3 q$ & $1 / 3^{x}$ & ND & $3 / 3$ & $3 / 3$ & $1 / 3$ & $3 / 3$ & $3 / 3$ & $2 / 3$ & $2 / 3$ \\
\hline
\end{tabular}

a aborted fetuses.

b experimentally BVDV-infected fetuses (Ohmann et al. $1981 \mathrm{~b}$ ).

c the isolated bacterial flora was regarded as contamination.

$\mathrm{d}$ this group includes one sham-inoculated fetus (Ohmann et al. $1981 \mathrm{~b})$.

q stillborn or dead immediately after birth without preceding colostral intake.

$x$ BVDV was isolated and/or the BVDV-antigen was demonstrated in all positive cases.

y premature birth; the calves were killed or died shortly after birth.

$z$ number positive/number examined.

ND the test was not done.

The high immunoglobulin levels were correlated with isolation of BVDV or detection of viral antigen in tissues in 12 animals $(70.6 \%)$ and with pathological lesions in 15 animals $(88.2 \%)$. The microbiological findings are obviously not representative of the causes of abortion in Danish cattle herds. The results of the immunological investigations are nevertheless in accordance with data previously reported from elsewhere (Schultz et al. 1971, Horner et al. 1973, Sawyer et al., Miller \& Quinn 1975, Kirkbride et al. 1977, Ellis et al.). Thus, high serum- 
T a ble 2. Results of the quantitative analysis, by radial immunodiffusion, for IgM, IgG and IgA in serum of control (abattoir)-, infected and aborted fetuses and newborn calves. Comparative data from the literature are included.

\begin{tabular}{|c|c|c|c|c|c|c|c|}
\hline \multirow{2}{*}{$\begin{array}{l}\text { Gestatio- } \\
\text { nal age } \\
\text { in months }\end{array}$} & \multirow{2}{*}{$\begin{array}{l}\text { Number of } \\
\text { objects in- } \\
\text { vestigated }\end{array}$} & \multicolumn{2}{|c|}{ IgM mg/100 ml } & \multicolumn{2}{|c|}{$\mathrm{IgG} \mathrm{mg} / 100 \mathrm{ml}$} & \multicolumn{2}{|c|}{ IgA $\mathrm{mg} / 100 \mathrm{ml}$} \\
\hline & & range & average & range & average & range & average \\
\hline $3-4$ & 1 & $\mathbf{0}$ & - & 0 & - & $\mathbf{0}$ & - \\
\hline $4-5$ & 4 & ND & - & 0 & - & ND & - \\
\hline $5-6$ & 9 & 0 & - & $0-3.75^{\mathrm{e}}$ & 0.42 & 0 & - \\
\hline $6-7$ & 3 & 0 & - & 0 & - & 0 & - \\
\hline $7-8$ & 2 & - & - & $0-10^{e}$ & 5 & 0 & 一 \\
\hline 8-9 & 1 & 0 & - & 230 & - & 0 & - \\
\hline \multicolumn{8}{|l|}{$\begin{array}{l}\text { aborted } \\
\text { and/or } \\
\text { infected }\end{array}$} \\
\hline $5-6$ & $4^{b}$ & $10-240$ & 73 & $11-85$ & 35 & $0-18^{\mathrm{e}}$ & 4.5 \\
\hline $71 / 2-81 / 2$ & $2^{\mathbf{a}}$ & $20-140$ & 80 & $65-210$ & 137 & 0 & - \\
\hline $81 / 2-9$ & $2^{\mathbf{y}}$ & $20-25$ & 22.5 & $30-265$ & 147 & $0-10^{e}$ & $\mathbf{5}$ \\
\hline 9 & $3^{q}$ & $36-110$ & 69 & $276-1240$ & 651 & $0-24^{\mathrm{e}}$ & 8 \\
\hline $\begin{array}{l}\text { pre- } \\
\text { colostral } \\
\text { calves } \\
\text { post- }\end{array}$ & 100 & $6-19$ & 11 & $10-27$ & 16 & ND & - \\
\hline $\begin{array}{l}\text { colostral } \\
\text { calves } \\
\text { (Sawyer } \\
\text { et al. } \\
1973 \text { ) }\end{array}$ & 23 & $101-301$ & 175 & $239-2400$ & 755 & ND & - \\
\hline
\end{tabular}

ND the serum was not tested.

a aborted fetuses.

b experimentally BVDV-infected fetuses (Ohmann et al. $1981 \mathrm{~b}$ ).

e only one positive in the group.

q stillborn or dead immediately after birth without preceding colostral intake.

y premature birth; the calves were killed or died shortly after birth.

immunoglobulin concentrations in aborted fetuses and calves dead without preceding colostral intake may be a weighty indication of fetal infection. It is concluded that screening of immunoglobulins in bovine fetuses may offer a valuable contribution to clarifying the causes of abortion among Danish cattle stock. 


\section{ACKNOWLEDGEMENTS}

The author thanks Dr. K. J. Sørensen, the State Veterinary Institute for Virus Research, Lindholm, for performing the virus isolations and Dr. M. Holm Jensen, the State Veterinary Institute for Virus Research, for contributions to the investigations for neutralizing antibodies. The studies have been supported by the Bernhard Bang Memorial Fund and by the V. A. Goldschmidt's Fund.

\section{REFERENGES}

Brambell, F. W. R.: The Transmission of Passive Immunity from Mother to Young. American Elsevier Publ. Comp., New York 1970.

Dalsgaard, K., E. Overby, J. J. Metzger \& A. Basse: Rapid method for screening of immunoglobulins in porcine fetuses, using rocket immunoelectrophoresis. Application of an interspecies reaction between human and porcine $\mu$-chain. Acta vet. scand. 1979, 20, 313-320.

Ellis, W. A., E. F. Logan \& J. J. O'Brian: Serum immunoglobulins in aborted and non-aborted bovine fetuses. Clin. exp. Immunol. 1978, 33, 136-141.

Horner, G. W., R. H. Johnson, D. P. Dennett \& W. R. Lane: A serological study of bovine foetal immunoglobulins. Aust. vet. J. $1973,49,325-329$.

Hubbert, W. T., O. H. V. Stalheim \& G. D. Booth: Changes in organ weights and fluid volumes during growth of the bovine fetus. Growth 1972, 36, 217-233.

Jensen, M. Holm: Detection of antibodies against hog cholera virus and bovine viral diarrhea virus in porcine serum. Acta vet. scand. 1981, 22, 85-98.

Kirkbride, C. A., D. Martinovich \& D. A. Woodhouse: Immunoglobulins and lesions in aborted bovine foetuses. N.Z. vet. J. 1977, 25, $180-187$.

Miller, R. B. \& P. J. Quinn: Observations on abortion in cattle: a comparison of pathological, microbiological and immunological findings in aborted foetuses and foetuses collected at abattoirs. Canad. J. comp. Med. 1975, 39, 270-290.

Ohmann, H. Bielefeldt: I. The bovine Immune System. II. Bovine viral diarrhoea virus-infections. Ph.D. thesis, Copenhagen 1981.

Ohmann, H. Bielefeldt, M. Holm Jensen, K. J. Sфrensen \& K. Dalsgaard: Demonstration of bovine viral diarrhea virus antigen in cryostat- and paraffin-sections of bovine tissues by the immunoperoxidase technique. Acta path. microbiol. scand. Sect. C $1981 \mathrm{a}, 89$, in press.

Ohmann, H. Bielefeldt, M. Holm Jensen, K. J. Sørensen \& K. Dalsgaard: Experimental fetal infection with bovine viral diarrhea virus (BVDV). In preparation, $1981 \mathrm{~b}$. 
Olitzki, A. L.: Studies on the antigenic structure of virulent and nonvirulent Brucellae with the aid of agar gel precipitation technique. Brit. J. exp. Pathol. 1959, 40, 432-440.

Sawyer, M., B. I. Osburn, H. D. Knight \& J. W. Kendrick: A quantitative serologic assay for diagnosing congenital infections of cattle. Amer. J. vet. Res. 1973, 34, 1281-1284.

Schultz, R. D.: Developmental aspects of the fetal bovine immune response: a review. Cornell Vet. 1973, 63, 507-535.

Schultz, R. D., F. Confer \& H. W. Dunne: Occurrence of blood cells and serum proteins in bovine fetuses and calves. Canad. J. comp. Med. 1971, 35, 93-98.

Silverstein, A. M., G. J. Thorbecke, K. L. Kraner \& R. J. Lukes: Foetal responses to antigenic stimulus. III. Gamma-globulin production in normal and stimulated foetal lambs. J. Immunol. 1963, 91, $384-395$.

\section{SAMMENDRAG}

Immunoglobulin niveau hos ikke-aborterede og aborterede fostre fra danske kvægbesætninger.

Anvendeligheden af serologiske tests, som et bidrag til diagnostisering af intrauterine infektioner, blev unders $\varnothing$ gt på et dansk kvægmateriale. Fostre fra slagtekvæg, eksperimentelt inficerede og spontant aborterede fostre samt præmature og d $\varnothing$ df $\varnothing$ dte kalve blev underkastet makro- og mikroskopiske, mikrobiologiske og serologiske unders $\emptyset$ gelser. Sidstnævnte omfattede raket immunoelektroforese og radial immundiffusion.

Immunoglobuliner var kun påviselige i små mængder hos ganske få fostre fra slagtekvæg, mens sera fra fostre og kalve med patologiske forandringer og/eller verificeret infektion indeholdt betydelige mængder IgM og IgG. IgA kunne også påvises i sera fra denne individgruppe. Resultaterne viser den diagnostiske betydning af en immunoglobulinbestemmelse for aborterede fostre og d $\varnothing \mathrm{df} \phi \mathrm{dte}$ kalve.

(Received July 13, 1981).

Reprints may be requested from: H. Bielefeldt Ohmann, the Department of Pathology, Royal Veterinary and Agricultural University, Bülowsvej 13, DK-1870 Copenhagen V, Denmark. 